or a hormone called erythropoietin (EPO) that raises the number of oxygencarrying red blood cells.

EPO abuse is already thought to be rife in many sports, including cycling - a whole team was expelled from the 1998 Tour de France for using it - but tests have been developed that can find synthetic versions of the hormone injected into the body (see Nature 407, 124; 2000). Introducing the gene coding for EPO would circumvent the tests, however, because the extra hormone produced would effectively be endogenous.

The artificial gene could be delivered to the body in several different ways, experts say. Perhaps the easiest method would be to inject the DNA directly into the muscle. But more efficient techniques using viruses or modified cells from the patient are also being developed.

One problem that currently prevents the clinical use of these techniques is the difficulty of controlling which tissues receive the gene. Schjerling says this would be of little concern to an athlete who just wants a short-term boost in hormone levels. Equally, doubts about whether the genes would keep functioning over time would not concern someone preparing for a one-off event such as the Olympics.

Gene doping of this sort would be difficult to expose. "The DNA of the artificial gene itself can be detected," says Schjerling, "but this requires that the sequence be known and that a sample of the tissue containing it can be acquired."

Even if the risk of detection was small, the risk to the athlete's health probably would not be. This is where the almost fanatical desire of athletes to excel raises problems, according to some of those present at the London meeting. Several cyclists are already thought to have died from EPO use, as the marked increase in circulating red blood cells severely thickens the blood, increasing the risk of clots and strokes.

In animal studies undertaken at the Chiron Corporation in Emeryville, California (S. Zhou, J. E. Murphy, J. A. Escobedo \& V. J. Dwarki, Gene Therapy 5, 665-670; 1998), the levels of red blood cells in baboons given experimental EPO gene therapy rose so sharply (from 40 to $75 \%$ in 10 weeks) that their blood had to be regularly diluted to keep them alive.

Theodore Friedmann, director of the gene-therapy programme at the University of California, San Diego, and a member of the WADA health, medical and research committee, says gene doping may occur sooner than people think. "The technology needed for a rogue attempt won't take that long to develop," he says. Although he thinks it unlikely that any athlete has yet tried it, he adds: "We all think there will be an attempt to do so."

\title{
Cell biologist quits editorial board over cloning paper
}

\section{Jonathan Knight, San Francisco}

Stem-cell pioneer John Gearhart has resigned from the editorial board of the biomedical journal that last month published a controversial paper claiming the creation of the first cloned human embryos.

Gearhart, a biologist at Johns Hopkins University in Baltimore, Maryland, says that in agreeing to publish the work, the journal had failed to uphold scientific standards.

The article appeared in the 26 November issue of the online journal e-biomed: The Journal of Regenerative Medicine (2, 25-31; 2001), published by New York-based Liebert.

Using the technique that created Dolly the sheep, the researchers, led by Jose Cibelli and Michael West of Advanced Cell Technology, a biotechnology firm in Worcester, Massachusetts, transferred nuclei from human cumulus cells, which surround eggs after ovulation, to human eggs (see Nature $414,477 ; 2001)$. A few of the eggs divided once or twice before they died.

The company claimed that it had finally cloned humans, adding that it had achieved an important first step in developing a technology that will ultimately revolutionize medicine.

But Gearhart says: "I don't think they have come anywhere near the mark of what it would take to prove that claim." He argues that the research is lacking in several important respects, such as its failure to provide evidence that the DNA in the dividing eggs actually came from the donor cell, or that it was functional.

Gearhart says he sought an explanation from the journal's editor-in-chief William Haseltine - chairman of Human Genome Sciences, a Maryland-based biotechnology company - as to how the paper passed editorial muster, but that none was forthcoming. He says he informed Haseltine of his decision to resign in an e-mail on 3 December.

Haseltine defends the decision to publish the paper. "Our reviewers thought it was an advance over what had been done before," he says. "It is not the ultimate word in embryogenesis, but it has not been described as that."

\section{Anthrax evidence implies US culprit}

\section{David Adam}

The investigation into the anthrax attacks in the United States may be homing in on the unsettling prospect that a researcher from America's own biological weapons programme is responsible.

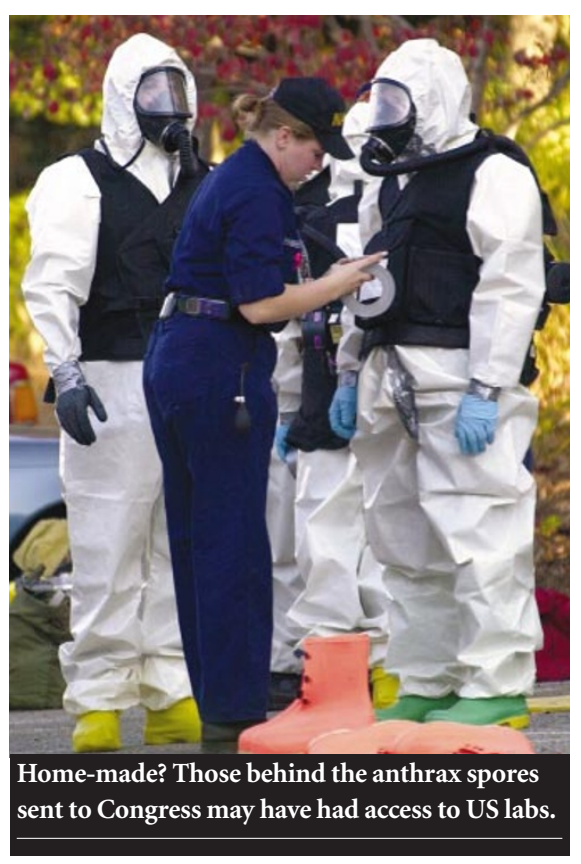

Barbara Rosenberg, a microbiologist at the State University of New York who chairs the biological weapons working group at the Federation of American Scientists, claimed this week that the investigations point to a microbiologist who once had access to weaponized anthrax in a US government lab. "I think the FBI knows it and I think they're looking into it," she says.

Rosenberg voiced her concerns at the Biological Weapons Convention meeting in Geneva on 21 November and then posted them on a listserv hosted by the Stockholm International Peace Research Institute.

The FBI has already indicated that it believes the anthrax culprit is probably based in the United States and recently confirmed that it is investigating US labs capable of producing the high-quality powdery form of the bacteria used in the attacks.

Rosenberg argues, among other things, that tests on the anthrax samples have revealed the presence of a chemical known to have been used in the US process that turns wet slurries of anthrax culture into spores suitable for weapons.

Other scientists involved in bioweapons research have reacted more cautiously. "The general outline has some credence but it is by no means certain," one said. 